Vol. 20(2011): 3-14.

\title{
Pests and diseases in a changing climate: a major challenge for Finnish crop production
}

\author{
Kaija Hakala, Asko O. Hannukkala, Erja Huusela-Veistola, Marja Jalli and Pirjo Peltonen-Sainio \\ MTT Agrifood Research Finland, Plant Production Research, FI-31600 Jokioinen, Finland, \\ email: kaija.hakala@mtt.fi
}

\begin{abstract}
A longer growing season and higher accumulated effective temperature sum (ETS) will improve crop production potential in Finland. The production potential of new or at present underutilised crops (e.g. maize (Zea mays L.), oilseed rape (Brassica napus L.), lucerne (Medicago sativa L.)) will improve and it will be possible to grow more productive varieties of the currently grown crops (spring wheat (Triticum aestivum L.), barley (Hordeum vulgare L.), oats (Avena sativa L.)). Also cultivation of autumn sown crops could increase if winters become milder and shorter, promoting overwintering success. Climatic conditions may on the other hand become restrictive in many ways. For example, early season droughts could intensify because of higher temperatures and consequent higher evaporation rates. Current low winter temperatures and short growing season help restrict the development and spread of pests and pathogens, but this could change in the future. Longer growing seasons, warmer autumns and milder winters may initiate new problems with higher occurrences of weeds, pests and pathogens, including new types of viruses and virus vectors. Anoxia of overwintering crops caused by ice encasement, and physical damage caused by freezing and melting of water over the fields may also increase. In this study we identify the most likely changes in crop species and varieties in Finland and the pest and pathogen species that are most likely to create production problems as a result of climate change during this century.
\end{abstract}

Key-words: climate change, crop, overwintering, pathogen, pest, virus, vector, winter 


\section{AGRICULTURAL AND FOOD SCIENCE}

\section{Hakala, K. et al. Pests and diseases in a changing climate}

\section{Introduction}

Finland lies between latitudes $60^{\circ}$ and $70^{\circ} \mathrm{N}$, but despite its northern location supports active agriculture on about 2.3 million hectares of arable land almost throughout the country, even beyond the Arctic Circle. This makes Finland the northernmost country in the world with successful agriculture. However, short, cool growing seasons, a low effective temperature sum (ETS, base temperature $+5{ }^{\circ} \mathrm{C}$ for crops commonly cultivated in Finland) and long, harsh winters with thick snow cover limit effective production of most crops (Mela 1996) and yields per unit area remain significantly lower than in Sweden and Denmark (FAO 2010). Moreover, frosts disrupt the growing season till mid June and from mid August (Mela 1996), affecting frost sensitive crops such as maize (Zea mays L.). Because of the limiting conditions, climate warming with higher ETS, a longer growing season and milder winters is expected to have beneficial effects on Finnish agriculture (Mela 1996), in contrast to more southern countries such as those around the Mediterranean that may face serious drought problems as a consequence of climate change (IPCC 2007b).

While crop production is generally expected to benefit from climate change in Finland (PeltonenSainio et al. 2009b), problems with weeds, pests and pathogens, including new types of viruses and virus vectors, are expected to increase (Tiilikkala et al. 2010). Extra investment in plant protection measures, as well as the possible yield losses caused by the higher pest and pathogen pressure in the future, could reduce the net profit that Finnish farmers are expected to gain as a consequence of beneficial changes in climate. This review focuses on both the prospects for agriculture and the problems that Finnish agriculture is already experiencing and will continue to experience in the future in a changed climate.

\section{Climate change in the northern latitudes}

The average annual global temperature has increased $0.76^{\circ} \mathrm{C}$ during the past century (IPCC 2007a). During the most recent decades and especially in the 2000s the increase has accelerated, the period 1995-2006 being the warmest ever recorded (IPCC 2007a). In Fennoscandia, the growing season has become one to three weeks longer during 1890-1997, with the lengthening taking place both at the start and at the end of the growing season (Carter 1998). At the same time, the ETS has increased, though without affecting the growing season intensity (average temperature during growth season). In Fennoscandia in general, the lengthening has been most noticeable at the end of the growing season, but in Finland it has taken place more at the beginning (Carter 1998). On average, since the 1960s there has been a trend of the growing season starting 2.1 days earlier per decade in the east and north of Finland, and 2.8 days earlier per decade in the west, with the pace of the development accelerating since the 1980s (Kaukoranta and Hakala 2008).

The increase in annual temperatures has been predicted to continue, with a greater increase at higher than at lower latitudes (IPCC 2007a). Temperatures are also predicted to increase more in winter than in summer (IPCC 2007a). Thus, in winter the temperatures would increase (compared with the period 1961-1990 and depending on scenario) $1.2-5.0^{\circ} \mathrm{C}$ by the 30 year period centred on $2025,2.0-7.8^{\circ} \mathrm{C}$ by the 30 year period centred on 2055 and $3.7-10.9^{\circ} \mathrm{C}$ by the 30 year period centred on 2085 (later, 2025, 2055 and 2085, respectively) (Jylhä et al. 2004). In summer the corresponding increase would be $0.6-1.6,1.1-3.9$ and $1.6-5.5^{\circ} \mathrm{C}$ by 2025,2055 and 2085 . In the spring and in the autumn the predicted changes in average temperatures would be intermediate between the winter and summer figures. Furthermore, with increasing temperatures the length of the growing season and the ETS accumulated during the growing season will continue to increase. In general the growing season is expected to become 39-47 days longer by 2085 in northern Europe, compared with a baseline period of 1961-1990, with a stronger effect at the end than at the start of the growing season (Fronzek and Carter 2007). In Jokioinen, in southern Finland ( $\left.60^{\circ} 49^{\prime} \mathrm{N}, 23^{\circ} 29^{\prime} \mathrm{E}\right)$, among one of the best crop production regions in Finland, the thermal growing season is expected to lengthen 
Vol. 20(2011): 3-14.

from 169 days at present (1971-2000) to 181 days in 2025, 196 days in 2055 and 219 days in 2085. The ETS will increase from about 1200 degree days $\left({ }^{\circ} \mathrm{Cd}\right)$ at present to about $1370{ }^{\circ} \mathrm{Cd}$ in 2025 , $1580^{\circ} \mathrm{Cd}$ in 2055 and $1860^{\circ} \mathrm{Cd}$ in 2085 (PeltonenSainio et al. 2009c). At the same time the beginning of the growing season would be 5, 9 and 22 days earlier and the end of growing season 6, 16 and 27 days later in 2025, 2055 and 2085 respectively than at present, according to the A2 scenario of the IPCC (Nakicenovic et al. 2000, Peltonen-Sainio et al. 2009c). Over the same time, extreme climatic events such as heat waves and heavy rains are predicted to increase (IPCC 2007a).

Climate change will lengthen the growing season and increase the ETS of the growing season markedly. However, when much of the increase in the growing season length will take place in the autumn, the plants that are dependent on radiation to produce biomass will benefit only partly from the warmer conditions. Also autumn rains could hamper field work to an even greater extent in the future than at present (Jylhä et al. 2004). Thus when crop production potential is evaluated on the basis of ETS and growing season length, adverse climatic conditions in the autumn have to be taken into account. However, while these conditions limit crop production, they do not necessarily limit pest and pathogen proliferation, which can continue in wet conditions and low light levels. In the spring, again, neither radiation levels nor temperatures, according to the present scenarios, will be limiting crop production starting from the beginning of April (Peltonen-Sainio et al. 2009c). Then, however, the remaining snow cover and excess field moisture could hamper field work (Carter 1998, PeltonenSainio et al. 2009b). On average, the period from 15 April to 30 September would most probably represent the technically feasible crop growing season in Finland in the future (Peltonen-Sainio et al. 2009b, 2009c), while pests and pathogens would most probably thrive over a longer period, at least for the period that the calculated growing season with an ETS above $5^{\circ} \mathrm{C}$ might suggest (Carter et al. 1996).

\section{A new era for northern crop production}

According to Peltonen-Sainio et al. (2009b), the ETS of the technically feasible crop growth period would increase by about $160^{\circ} \mathrm{Cd}$ by $2025,320-340$ ${ }^{\circ} \mathrm{Cd}$ by 2055 and by $550{ }^{\circ} \mathrm{Cd}$ by 2085 , if emissions continue as described by the IPCC scenario A2 (Nakicenovic et al. 2000). This would mean, among other things, that new crops such as forage maize, lupin (Lupinus angustifolius L.) (Peltonen-Sainio et al. 2009b) and oilseed rape (Brassica napus L.) (Peltonen-Saino et al. 2009a), which demand high ETS to mature, and have up to now been cultivated on very limited areas in Finland, could be cultivated successfully on larger areas. Also some promising minor crops such as flax (Linum usitatissimum L.), buckwheat (Fagopyrum esculentum Mill.), faba bean (Vicia faba L.) and sunflower (Helianthus annuus L.) might be taken into more extensive cultivation (Peltonen-Sainio et al. 2009b). In addition to this, the longer growing season would mean that more productive varieties of the presently cultivated common crops, barley (Hordeum vulgare L.), oats (Avena sativa L.) and wheat (Triticum aestivum L.) could be taken into use and the cultivated area of these crops would increase (Table 1).

\section{Areas and importance of autumn sown cereals and perennials will increase}

\section{Autumn sown cereals}

In the future cultivation of most spring sown crops will not be limited by ETS in Finland, even at the borders in Lapland. At the same time, however, drought problems are likely to get more serious during the spring and early summer despite the slight increase in precipitation expected with climate change (Jylhä et al. 2004, Peltonen-Sainio et al. 2011b). Therefore there will be increasing need for autumn sown crops in the southern and central parts of Finland. For overwintered crops with well established root systems, increased precipitation in 


\section{AGRICULTURAL AND FOOD SCIENCE}

\section{Hakala, K. et al. Pests and diseases in a changing climate}

Table 1. Novel or minor spring sown crops currently grown (1971-2000, centred on 1985) or promising crops for Finland following climate change according to a 30 year period centred on 2025, 2055 and 2085 (adapted from Peltonen-Sainio et al. 2009b). ETS, effective temperature sum with threshold temperature $5{ }^{\circ} \mathrm{C}$, except for maize, $10^{\circ} \mathrm{C}$. Buckwheat needs $10^{\circ} \mathrm{C}$ for emergence (Montonen and Kontturi 1997). Southern Finland (South), up to $62^{\circ} \mathrm{N}$, central Finland (Central), up to $64^{\circ} \mathrm{N}$, northern Finland (North), up to $66^{\circ} \mathrm{N}$, Lapland, up to $68^{\circ} \mathrm{N}$, north Lapland (Lapland N), up to $70^{\circ} \mathrm{N}$. South+, coastal area at about $60^{\circ} \mathrm{N}$.

\begin{tabular}{|c|c|c|c|c|c|}
\hline Crop & $\begin{array}{l}\text { ETS } \\
\text { required }\end{array}$ & $\begin{array}{c}\text { Suitable in } 1985 \\
\text { up to }\end{array}$ & $\begin{array}{c}\text { Suitable in } 2025 \\
\text { up to }\end{array}$ & $\begin{array}{c}\text { Suitable in } 2055 \\
\text { up to }\end{array}$ & $\begin{array}{c}\text { Suitable in } 2085 \\
\text { up to }\end{array}$ \\
\hline $\begin{array}{l}\text { Spring barley } \\
\text { Hordeum vulgare L. }\end{array}$ & 890 & North & North & Lapland & Lapland N \\
\hline $\begin{array}{l}\text { Spring oats } \\
\text { Avena sativa } \mathrm{L} .\end{array}$ & 960 & Central & North & Lapland & Lapland N \\
\hline $\begin{array}{l}\text { Spring wheat } \\
\text { Triticum aestivum } \mathrm{L} \text {. }\end{array}$ & 990 & Central & North & Lapland & Lapland N \\
\hline $\begin{array}{l}\text { Spring turnip rape } \\
\text { Brassica rapa } \mathrm{L} \text {. }\end{array}$ & 1010 & Central & North & Lapland & Lapland N \\
\hline $\begin{array}{l}\text { Spring oilseed rape } \\
\text { Brassica napus } \text { L. }\end{array}$ & 1090 & South & Central & North & Lapland \\
\hline $\begin{array}{l}\text { Buckwheat } \\
\text { Fagopyrum esculentum Mill. }\end{array}$ & 900 & North & Lapland & Lapland & Lapland N \\
\hline $\begin{array}{l}\text { Field pea } \\
\text { Pisum sativum } \mathrm{L} .\end{array}$ & $930-980$ & Central-North & Lapland & Lapland & Lapland N \\
\hline $\begin{array}{l}\text { Faba bean } \\
\text { Vicia faba } \mathrm{L} .\end{array}$ & 1060 & South & Central & North & Lapland \\
\hline $\begin{array}{l}\text { Flax } \\
\text { Linum usitatissimum L. }\end{array}$ & 1040 & Central & North & Lapland & Lapland N \\
\hline $\begin{array}{l}\text { Hemp } \\
\text { Cannabis sativa } \mathrm{L} .\end{array}$ & 1150 & South & Central & North & Lapland \\
\hline $\begin{array}{l}\text { Forage Maize } \\
\text { Zea mays L. }\end{array}$ & $700-850$ & Not suitable & South + & South & Central \\
\hline $\begin{array}{l}\text { Sunflower } \\
\text { Helianthus annuus L. }\end{array}$ & 1100 & South & Central & North & Lapland N \\
\hline
\end{tabular}

the winter (Jylhä et al. 2004) would secure sufficient soil moisture for early growth in spring and early summer. Currently overwintering crops are sown only in the south of Finland. Increase in temperatures, especially during the winter, is expected to gradually improve conditions for autumn sown crops to overwinter, thus facilitating a change from spring sown to autumn sown crops (Peltonen-Sainio et al. 2009b). For example, winter wheat, which is currently restricted to southern Finland up to about 61 ${ }^{\circ} \mathrm{N}$, could be grown successfully up to $64^{\circ} \mathrm{N}$ in 2025 , and by 2055 up to $66^{\circ} \mathrm{N}$. Winter rye (Secale cereale L.) is currently grown almost throughout Finland, but the yield levels drop dramatically north of 64
${ }^{\circ} \mathrm{N}$. By 2025 the area for winter rye cultivation could expand to include all Finland (Peltonen-Sainio et al. 2009b). Even though overwintering problems will not be overcome soon, despite increases in winter temperatures (Peltonen-Sainio et al. 2011a), the number of winter days (days with average temperatures below $0{ }^{\circ} \mathrm{C}$ ) will gradually decrease. There is likely to be fewer than 100 winter days in southern Finland by 2055, and, depending on the climate change scenario, fewer than 100 winter days up to $66^{\circ} \mathrm{N}$ (scenario A2) or up to $62^{\circ} \mathrm{N}$ (B1 scenario) by 2085 (Peltonen-Sainio et al. 2009b). By 2085, if climate warming occurs according to scenario A2 (Nakicenovic et al. 2000), southern Finland 
Vol. 20(2011): 3-14.

might have winter conditions that resemble those of today's Denmark (1961-1990, Tveito et al. 2001, Peltonen-Sainio et al. 2009b, 2009c). However, the overwintering problems will not all be solved by then, as frost periods with intermittent warm spells are still expected to occur in Finland up to the end of the 21 st century even according to the relatively high IPCC emission scenario A2 (Jylhä et al. 2008). Such conditions could be especially damaging for autumn sown crops, as when temperatures fluctuate around zero, snow melts and ice forms on the fields. This will cause ice encasement problems, such as anoxia, ice scorch and heaving, and maybe even frost damage if there is no protecting snow cover despite temperatures being well below zero (Hömmö 1994, Bélanger et al. 2002, Jylhä et al. 2008). For sensitive varieties of overwintering crops warm spells in mid-winter might also lead to decreased cold hardiness and increased susceptibility to frost damage (Bélanger et al. 2002). Increased physiological activity too early in the spring could lead to loss of reserve carbohydrates through respiration. This could result in reduced resistance against pathogens and weakened growth early in the season, when reserve carbohydrates are required for growth and maintenance of the photosynthesising leaves (Hakala and Pahkala 2003). Long and warm autumns could also lead to reduced cold hardening (Bélanger et al. 2002) and too dense canopies that favour pathogens (Serenius et al. 2005).

\section{Perennial grasses and forage legumes}

In experiments with simulated future conditions in Jokioinen, Finland, meadow fescue (Festuca pratensis L.) produced significantly higher yield when the growing season started earlier and finished later in a simulated warmer climate in the greenhouse (Hakala and Mela 1996). Furthermore, elevation of $\mathrm{CO}_{2}$ levels had a more marked effect on yield under the warmer conditions with a prolonged growing season (Hakala and Mela 1996). In addition to the lengthening of the growing season, overwintering conditions for perennial grasses and legumes could become better with climate change, when the snow cover during the winter thins and stays for a shorter period (Jylhä et al. 2008). Under the present climatic conditions, deep and long lasting snow cover often favours low temperature fungi that damage the canopy and reduce the yield of crops in the following growing season (Ylimäki 1969, Nissinen 1996, Yli-Mattila et al. 2010). On the other hand, without snow cover, perennial grasses and legumes can face the same problems as autumn sown cereals; ice encasement, ice scorch and heaving injury (Hömmö 1994), often followed by disease attacks (Ylimäki 1967). It is possible that before mild winters typical of regions such as Denmark and southern Sweden have reached Finland, cultivation of grasses and legumes may face new and severe problems due to unstable autumn and winter conditions.

The importance of perennial legumes in forage leys and as bioenergy crops is currently increasing and will probably continue to grow. Legumes fix atmospheric nitrogen and reduce the need for chemical nitrogen fertilisation, thereby helping to reduce greenhouse gas emissions that would otherwise result from the manufacture of the fertiliser. In addition, forage production and especially the production of perennial bioenergy crops, requires sustainable and cheap production technology because of the low price of the product. Leguminous crops could add nitrogen to the system in an efficient and economical way.

The most common perennial legume forage grown in Finland is red clover (Trifolium pratense L.) (Evira 2009). Some alsike clover (Trifolium hybridum L.) is also grown and some white clover (Trifolium repens L.) is a component of pastures (Evira 2009). According to Halling et al. (2004), both annual accumulation of degree days, especially during the regrowth period, and average daily temperatures during the growth period, are generally positively correlated with both red clover and white clover yield. This suggests that in the future longer and warmer growing seasons in Finland will promote clover yields. In northern European areas south of Finland, lucerne (Medicago sativa L.) is an important forage legume. It produces high yields and is very persistent in a ley (Halling et al. 2004). If growing conditions improve, lucerne might become a major forage crop also in Finland, but red 


\section{AGRICULTURAL AND FOOD SCIENCE}

\section{Hakala, K. et al. Pests and diseases in a changing climate}

clover will probably remain in cultivation because of its stable and nutritionally superior yield (Bertilsson and Murphy 2003, Dewhurst et al. 2003).

\section{Pest and pathogen problems in a changed climate with warmer and milder winters and autumns and with new crop forms and species}

The classic disease triangle emphasises that virulent pathogens cannot induce disease on a highly susceptible host if weather conditions are not favourable. In addition, the environment can influence host-pathogen interactions through growth and susceptibility of the host plant and reproduction, dispersal, survival, and activity of the pathogen. The impacts of environmental change on plant diseases can be positive, negative or neutral and the effects are highly localised (Ghini et al. 2008). Carter et al. (1996) showed that in the future pests and pathogens will exploit the longer growing season and milder winters at least as efficiently as the crops. Pests and pathogens are not as dependent on radiation as crops, thus their growth could exploit a much longer period of the year than the effective growing season for plants at average daily temperatures above $5^{\circ} \mathrm{C}$. With longer growing seasons and higher temperatures, development of pests is faster and the annual generations of multivoltine species could increase (Bale et al. 2002). With a longer growing season plant pathogens will thrive. For example, studies based on simulation models indicate that an increase of $1^{\circ} \mathrm{C}$ in mean temperature in southern Finland extends the period when potato late blight (Phytophthora infestans (Mont.) de Bary) control is necessary by $10-20$ days, which means $1-2$ more fungicide applications per season (Kaukoranta 1996). The need for plant protection measures for potato late blight control has already increased following climate change, and the epidemiology of the pathogen has also changed substantially (Hannukkala et al. 2007). As new crops are taken into active cultivation, their pests and diseases will gradually enter Finland.
Climate change will also affect the winter survival of overwintering plants such as grasses and autumn sown cereals. For example, red clover currently becomes less persistent the further north and east (continental) it is grown (Halling et al. 2004). The extent of this could be determined by the thickness and persistence of snow cover, which increase towards the north and inland (east). The pathogens that infect red clover, clover rot (Sclerotinia trifoliorum Erikss.) and root rot (several Fusariumspecies) thrive best under thick snow cover, and especially when snow cover stays for a long period (Ylimäki 1967, 1969, Willets and Wong 1980, Yli-Mattila et al. 2010). With milder winters and thinning of the snow cover red clover, as well as other perennial grasses and legumes, might survive better in Finnish leys, which will prolong the profitable period of yield production and thus reduce the cultivation costs.

\section{Examples of possible increased plant disease risks}

The shift towards autumn sown cereals will change the prevailing pathogen spectrum and increase the need for plant disease control during autumn. Eyespot (Oculimacula yallundae (Wallwork \& Spooner) Crous \& W. Gams and Oculimacula acuformis (Boerema, R. Pieters \& Hamers) Crous \& W. Gams, anamorf Pseudocercosporella herpothrichoides (Fron) Deighton) is a severe disease of winter wheat (Fitt et al. 1988), rye and perennial grasses (Cunningham 1981) in temperate regions, causing up to $50 \%$ yield losses (Fitt et al. 1988). In Finland this disease was frequently found in spring wheat throughout the country in 1946 - 1953 (Hårdh 1953). Eyespot was commonly found in some years in the 1960s, but was practically absent in $1975-1978$ (Mäkelä and Parikka 1980). In surveys carried out in the late 1980s and early 1990s eyespot was rare and it is not currently regarded as an important cereal disease in Finland (Hannukkala unpublished). Eyespot has, however, great potential to become a major stem base disease in a changed climate, as it already is in Denmark (Sindberg et al. 1994) 
Vol. 20(2011): 3-14.

and other countries with moist autumns (Fitt et al. 1988). The anamorphic spores of the pathogen infect hosts in the moist autumn conditions when the temperature is $8-21^{\circ} \mathrm{C}$. The apothecia of the fungus are produced on the bases and culms in straw stubble two months after harvest and mature ascospores spread during winter and early spring in the British climate (Dyer et al. 1994). Ascospores represent important source of infectious inoculum as well as a source of genetic variation for build up of fungicide resistance (Daniels et al. 1995). Predictions for future autumn conditions in Finland suggest that eyespot may have improved possibilities for proliferation in Finland.

Changing climate will also favour powdery mildew (Blumeria graminis (DC.) Speer) infections of winter wheat and barley (Gregory et al. 2009). The dynamics of barley powdery mildew epidemics will change, particularly when autumn sown barley is incorporated into production. Currently barley powdery mildew cannot overwinter in Finland as suitable hosts do not exist. In Denmark and southern Sweden, where winter barley is grown, powdery mildew is one of the most serious diseases (Bousset et al. 2002). Chemical control is frequently needed and rapid development of new races of both wheat and barley mildews will challenge resistance breeders in the future (Limpert et. al 1999). Also rusts, especially brown rust (Puccinia recondita Dietel \& Holw), could become an increasing problem. Winter cereals can be attacked already in autumn, which can have detrimental effects for overwintering of crops (Serenius et al. 2005). Climate warming can also have indirect effects by changing rust and powdery mildew resistance gene expression. Genes active against diseases at low $\left(10^{\circ} \mathrm{C}\right)$ temperatures can be turned off at high $\left(25^{\circ} \mathrm{C}\right)$ temperatures (Gregory et al. 2009).

Increase in production of autumn sown cruciferous oil seed crops will give rise to new disease problems that are currently negligible for spring sown cultivars. In the $1950 \mathrm{~s}$, when autumn sown oil seed crops were grown in Finland, Typhula setipes (Grev.) Berthier, among other low temperature fungi, caused serious winter damage (Jamalainen 1954). Wilt caused by Verticillium longisporum (C. Stark) Karapapa, Bainbr. \& Heale is a very serious problem for autumn sown oil seed crops in Denmark and southern Sweden (Johansson et al. 2006), but is currently very rare in Finland in spring sown oil seed crops (Hannukkala unpublished). However, in the future Finland may face a similar problem because the Finnish climate at the end of this century could resemble that of current day Denmark and southern Sweden (PeltonenSainio et al. 2009b).

In addition to the problems arising from increasing possibilities for cultivating overwintering crops, new possibilities for spring crop rotations may also cause problems with pathogens that have not been recorded in Finland. For example, introduction of maize into crop rotations with wheat could increase the importance of particular mycotoxin-producing Fusarium species, especially Fusarium graminearum Schwabe, as recorded elsewhere (Osborne and Stein 2007). F. graminearum under certain conditions produces the mycotoxin deoxynivalenol (DON) among other toxins (Birzele et al. 2002). F. graminearum is already present in Finland but other Fusarium species predominate (Uhlig et al. 2007). A warming climate and modified host range might also substantially change the propagation biology of the pathogen by favouring its sexual stage (Gibberella zeae (Schwein.) Petch) and increasing intra-population genetic diversity (Xu 2003).

Intensive agricultural systems encourage rapid evolution of plant pathogens. The plasticity of some agricultural systems could help to minimise negative impacts of climate change, for example, through new adapted cultivars (Chakraborty et al. 2000). Disease management strategies are designed with reference to the environment and could be affected by climate change. Fungicide residue dynamics could be affected by changes in temperature and precipitation, and changes in plant morphology or physiology resulting from climate change can influence the efficacy of fungicide action (Ghini et al. 2008). There is also evidence that some forms of disease resistance might be overcome more rapidly following changes in levels of $\mathrm{CO}_{2}$, ozone and UV-B. The greatest concern over the durability of host resistance is accelerated pathogen evolution (Chakraborty et al. 2000). Understanding the host- 


\section{AGRICULTURAL AND FOOD SCIENCE}

\section{Hakala, K. et al. Pests and diseases in a changing climate}

pathogen biology is the first step toward minimising the risks represented by novel plant diseases. Durable, race non-specific resistance incorporated into high yielding genotypes is the main method for managing obligate parasites of cereals. In addition to disease resistance, improved crop management methods, including crop rotation, will be necessary (Duveiller et al. 2007).

\section{Examples of possible increased pest risks}

Climate change will have a number of effects on developmental rate and phenology of crop plants that will alter the proliferation of associated pest species. The degree of damage suffered by a crop will depend on the synchrony between pest abundance and the most susceptible developmental stage of the crop (Van Emden and Way 1973). Direct climate change or changes in cropping practices, e.g. a shift in sowing time, could result in crops suffering variable levels of pest attack at vulnerable seedling stages (Huusela-Veistola et al. 2006). During warmer autumns damage by frit fly (Oscinella frit L.) and Hessian fly (Mayetiola destructor Say) in winter cereals will probably increase (Tiittanen 1959, Huusela-Veistola et al. 2006). Longer and warmer periods in autumn also enable extended flights of plant virus vectors such as Rhopalosiphum padi L. and Psammotettix alienus Dahlb. (Huusela-Veistola and Lemmetty 2005, Ewaldz et al. 2007). Therefore, the risk of BYDV (Barley Yellow Dwarf Virus) and WDV (Wheat Dwarf Virus) developing in winter cereals is likely to increase in the future (Harrington 2007, Huusela-Veistola 2007). However, viruses, vectors, host plants and abiotic factors are continuously changing and their interactions are complex and challenging to predict or manage (Harrington 2007, Canto et al. 2009).

Changes in crop production systems are likely to alter the composition of pest complexes. New crops represent new host plants and habitats and therefore pest problems are likely to increase as a new crop becomes widely grown. Climate change may increase the importance of some existing pests or enable colonisation by new pests previ- ously restricted by unfavourable low temperatures or shortage of suitable host plants. For example, the European corn borer, Ostrinia nubilalis Hübner, which nowadays feeds on alternative host plants in southern Finland, is likely to become a pest of maize as its cropping range expands northwards (Tiilikkala et al. 2010). Furthermore, frit fly and aphids, which are common insect pests of cereals in Finland, can also damage maize. In addition, the abundance of Rhopalosiphum maidis Fitch, which is vector of the RMV strain of BYDV, could increase in tandem with increased maize cropping and climate warming (Harrington 2007).

Increased cropping of winter oilseed crops could change the status and phenology of pests of cruciferous crops. For example, cabbage seed weevil (Cheutorrhynchus assimilis Payk) is phenologically synchronized with winter oilseed rape (Kevväi et al. 2006), whereas pollen beetles (Meligethes aeneus Fab.) are more problematic in spring oilseeds (Veromann et al. 2006). At present the number of important pest species of oilseed rape is higher in Denmark than in other Nordic countries (Menzler-Hokkanen et al. 2006). It is likely that pest problems and the need for insecticides in oilseed cropping will increase with climate change also in Finland. That will be problematic because pollen beetles resistant to insecticides (pyrethroids) have already been recorded in Sweden (Ekbom and Kuusk 2001) and in Denmark (Hansen 2003), and insecticide resistance is likely to develop also in Finland (Tiilikainen and Hokkanen 2008). Overall, selection of available insecticides is narrow. Pyrethroids are commonly used against pests of all field crops, which increases risk of pesticide resistance for other pest insects as well.

In the long run, climate change, especially warming of winters, could enable survival of year-round parthenogenetically reproducing anholocyclic forms of Rhopalosiphum padi, which are nowadays common in the UK (Tatchell et al. 1988) and France (Dedryver and Gellé 1982, Simon et al.1991) and have recently also been recorded in Poland (Ruszkowska 2007). Anholocyclic clones are important vectors of BYDV in winter cereals (Harrington 2002). Increased capacity for long-range migration and rapid rate of population 
Vol. 20(2011): 3-14.

increase make aphids effective colonists and important pests (Van Emden and Harrington 2007) that will have to be monitored more carefully in the future. On general, climate change will increase risk of entry and establishment of invasive alien pest species in Finland (Vänninen et al. 2011)

Frequency and amplitude of pest and pathogen outbreaks vary considerably in time and space. Climate change could increase variation among species, populations/strains of the same species, different seasons and localities, and therefore complicate forecasting of plant protection problems. Climate change will not only affect the distribution and abundance of pest populations, but also those of their host plants, competitors and natural enemies. Due to varying conditions and time scales definitive effects of these interactions will be difficult to predict (Thomson et al. 2009).

Climate change in conjunction with changed crop composition could indirectly affect plant protection. For example, in UK, winter oilseed rape provides a suitable overwintering habitat for anholocyclic peach aphid, Myzus persicae Sulz. (Cocu et al. 2005), which is the most important vector of potato virus Y (PVY) (Radcliffeand Ragsdale 2002). In Nordic countries, many other aphid species, such as Rhopalosiphum padi, Aphis fabae Scopoli, A. frangulae Kalt., A. nasturtii Kalt., Brachycaudus helichrysi Kalt., Acyrthosiphon pisum Harris, Phorodon humili Schrank, Metopolophium dirhodum Walker and Cryptomyzus galeopsidis Kalt. are more important PVY vectors at the moment (Kurppa and Rajala 1986, Sigvald 1989, Kirchner et al. 2009) but comparable vicarious effects as in the case of peach aphid in UK are possible and unforeseeable when crop assortment and weather conditions alter. Moreover, although forage grasses and legumes incur minor pest damage they can act as a reservoir for slugs, aphids and BYDV, which can cause problems in neighbouring winter cereals. Overall expansion of winter oilseed crops, winter cereals, perennial grasslands and different winter vegetation management, such as undersown catch crops, could create "green bridges" for pests and pathogens. In parallel, the peak of chemical control is likely to change from early summer to autumn, which can increase leaching of pesticide residues. Increased need of chemical control with climate change in tandem with risk of pesticide resistance and restrictions of pesticide use create more challenges for plant protection. Therefore, integrated pest management methods and alarm systems that support decision making in plant protection, as well as resistant cultivars and adequate crop rotations should be used to minimize the problems caused by increased need for plant protection.

\section{Conclusions}

While the predicted climate change generally improves crop production possibilities in Finland, the accompanying threats represented by pests and pathogens have to be taken into account when making predictions and developing adaptation practices for Finnish crop production. Because of the huge range of interactions and outcomes associated with a changing climate and different cropping systems it is important to avoid drawing overly simplistic conclusions (Morecroft et al. 2009). However, an increased use of overwintering crops in particular poses substantial challenges for Finnish crop production. E.g. emphasis of chemical control is likely to change from early summer to autumn, which can increase leaching of pesticide residues, especially as winter temperatures and precipitation are predicted to increase. In addition to environmental problems, increased need of chemical control in tandem with risk of pesticide resistance and restrictions of pesticide use are likely to create more challenges for plant protection. Therefore, integrated pest management methods and alarm systems that support decision making in plant protection measures have to be used efficiently in order to realise the benefits of improved crop growth conditions in the future. Resistant cultivars, adequate crop rotations and sustainable control methods are crop management practices that can be used to minimize plant protection problems and adverse effects of the protection measures to the environment. 


\title{
AGRICULTURAL AND FOOD SCIENCE
}

\author{
Hakala, K. et al. Pests and diseases in a changing climate
}

\section{References}

Bale, J.S., Masters, G.J., Hodkinson, I.D., Awmack, C., Bezemer, T.M., Brown, V.K., Butterfield, J., Buse, A., Coulson, J.C., Farrar, J., Good, J.E.G., Harrington, R., Hareley, S., Jones, T.H., Lindroth, R.L., Press, M.C., Symrnioudis, I., Watt, A.D. \& Whittaker, J.B. 2002. Herbivory in global climate change research: direct effects of rising temperature on insect herbivores. Global Change Biology 8: 1-16.

Bélanger, G., Rochette, P., Castonguay, Y., Bootsma, A., Mongrain, D. \& Ryan, D.A.J. 2002. Climate change and winter survival of perennial forage crops in eastern Canada. Agronomy Journal 94: 1120-1130.

Bertilsson, J. \& Murphy, M. 2003. Effects of feeding clover silages on feed intake, milk production and digestion in dairy cows. Grass and Forage Science 58: 309-322.

Birzele, B., Meier, A., Hindorf, H., Krämer, J. \& Dehne, H.W. 2002. Epidemiology of Fusarium infection and deoxynivalenol in winter wheat in the Rhineland, Germany. European Journal of Plant Pathology 108: 667-663.

Bousset, L., Hovmøller, M.S., Caffier, V., de VallaviellePope, C. \& Østergård, H. 2002. Observed and predicted changes over eight years in frequency of barley powdery mildew avirulent to spring barley in France and Denmark. Plant Pathology 51: 33-44.

Canto, T., Aranda, M.A. \& Fereres, A. 2009. Climate change effects on physiology and population processes of hosts and vectors that influence the spread of hemipteran-borne plant viruses. Global Change Biology 15: 1884-1894.

Carter, T.R. 1998. Changes in the thermal growing season in Nordic countries during the past century and prospects for the future. Agricultural and Food Science in Finland 7: 161-179.

Carter, T.R., Saarikko, R.A. \& Niemi, K.J. 1996. Assessing the risks and uncertainties of regional crop potential under a changing climate in Finland. Agricultural and Food Science in Finland 5: 329-350.

Chakraborty, S., Tiedemann, A.V. \& Teng, P.S. 2000. Climate change: potential impact on plant diseases. Environmental Pollution 108: 317-326.

Cocu, N., Harrington, R., Rounsevell, D.A., Worner, S.P., Hulle, M. \& The EXAMINE project participants 2005 . Geographical location, climate and land use influence on the phenology and numbers of the aphid, Myzus persicae, in Europe. Journal of Biogeography 32: 615-632.

Cunningham, P.C. 1981. Occurrence, role and pathogenic traits of a distinct pathotype of Pseudocercosporella herpothrichoides. Transactions of the British Mycological Society 76: 3-15.

Daniels, A., Papaikonomou, M, Dyer, P.S. \& Lucas, J.A. 1995. Infection of wheat seedlings by ascospores of Tapesia yallundae - morphology of the infection process and evidence for recombination. Phytopathology 85: 918-927

Dedryver, C.A. \& Gelle, A. 1982. Biologie des puceronsdes céréales dans l'ouest de la France. IV. Etude de I'hivernation des populations anholocycliques de Rhopalosiphum padi L., Metopolophium dirhodum Wik et Sitobion avenae F. sur repousses de céréales dans trois stations de Bretagne et du Bassin parisien. Acta Oecologica Applicata 3: 321-342.

Dewhurst, R.J., Fisher, W.J., Tweed, J.K.S. \& Wilkins, R.J. 2003. Comparison of grass and legume silages for milk production. 1. Production responses with different levels of concentrate. Journal of Dairy Science 86: 2598-2611.

Duveiller, E., Singh, R.P. \& Nicol, J. M. 2007. The challenges of maintaining wheat productivity: pests, diseases, and potential epidemics. Euphytica 157: 417-430.

Dyer, P.S., Bateman, G.L., Lucas, J.A. \& Peberdy, J. F. 1994. Seasonal development of apothecia of the cereal eyespot pathogen Tapesia yallundae on straw stubble in the UK. Annals of Applied Biology 125: 489-500.

Ekbom, B. \& Kuusk, A-K. 2001. Pollen beetles (Meligethes aeneus) and resistance against pyrethroids. Växskyddsnotiser 65: 39-42.

Ewaldz, T., Sigvald, R., Berg, G. \& Larsson, H. 2007. Barley Yellow Dwarf Virus on winter cereals in Sweden. In: NJF Seminar 402: Virus vector management in a changing climate, preliminary report, Kristianstad, Sweden, 9-11 October 2007. p. 67-69.

Evira 2009. Finnish Food Safety Authority. Available on the internet: www.evira.fi. Cited on 1 December 2009.

FAO 2010. Homepage of Food and Agriculture Organization of the United Nations. Available on the internet: http://faostat.fao.org. Cited on 4 January 2010.

Fitt, B.D.L, Goulds, A. \& Polley, R.W. 1988. Eyespot (Pseudocercosporella herpothrichoides) epidemiology in relation to prediction of disease severity and yield loss in winter wheat - a review. Plant Pathology 37: 311-328.

Fronzek, S. \& Carter, T.R. 2007. Assessing uncertainties in climate change impacts on resource potential for Europe based on projections from RCMs and GCMs. Climatic Change 81: 357-371.

Ghini, R., Hamada, E. \& Bettiol, W. 2008. Climate change and plant diseases. Scientia Agricola 65: 98-107.

Gregory, P.J., Johnson, S.N., Newton. A.C. \& Ingram, J.S.I. 2009. Integrating pests and pathogens into the climate change/food security debate. Journal of Experimental Botany 60: 2827-2838.

Hakala, K. \& Mela, T. 1996. The effects of prolonged exposure to elevated temperatures and elevated $\mathrm{CO}_{2}$ levels on the growth, yield and dry matter partitioning of fieldsown meadow fescue (Festuca pratensis, cv. Kalevi). Agricultural and Food Science in Finland 5: 285-298.

Hakala, K. \& Pahkala, K. 2003. Comparison of central and northern European winter rye cultivars grown at high latitudes. Journal of Agricultural Science 141: 169-178.

Halling, M.A., Topp, C.F.E. \& Doyle, C.J. 2004. Aspects of the productivity of forage legumes in Northern Europe. Grass and Forage Science 59: 331-344.

Hannukkala, A., Kaukoranta, T., Lehtinen, A. \& Rahkonen, A. 2007. Late-blight epidemics on potato in Finland, 1933-2002; increased and earlier occurrence of epidemics associated with climate change and lack of rotation. Plant Pathology 56: 167-176.

Hansen, L.M. 2003. Insecticide-resistant pollen beetles (Meligethes aeneus F.) found in Danish oilseed rape (Brassica napus L.) fields. Pest Management Science 59: 1057-1059.

Hårdh, J.E. 1953. Kevätvehnän kahutähkäisyydestä sekä sen syistä Suomessa [English summary: On the shrivelheads of spring wheat and their causes in Finland]. Publi- 
Vol. 20(2011): 3-14.

cations of the Finnish State Agricultural Research Board 140, Helsinki. 152 p.

Harrington, R. 2002. BYDV: The heat is on. In: Henry, M. \& McNab, A. (eds), Barley Yellow Dwarf Disease: Recent Advances and Future Strategies. CIMMYT, Mexico, D.F. p. 34-39.

Harrington, R. 2007. Viruses, vectors, host plants and environment: From complexity to control. In: NJF Seminar 402: Virus vector management in a changing climate, preliminary report, Kristianstad, Sweden, 9-11 October 2007. p. 9-11.

Hömmö, L.M. 1994. Resistance of winter cereals to various winter stress factors - inter- and intraspecific variation and the role of cold acclimation. Agricultural Science in Finland 3, Suppl. 1 (PhD Thesis, Agricultural Research Centre of Finland).

Huusela-Veistola, E. 2007. Overview of vectors of cereal viruses in Finland. In: NJF Seminar 402: Virus vector management in a changing climate, preliminary report, Kristianstad, Sweden, 9-11 October 2007. p. 43-44.

Huusela-Veistola, E.\& Lemmetty, A. 2005. Viirukaskaan levittämää vehnän kääpiökasvuvirusta Suomessa. Kasvinsuojelulehti 38 (1): 8-10. (In Finnish.)

Huusela-Veistola, E., Jalli, H., Salonen, J., Pahkala, K. \& Laine, A. 2006. Sowing time affects the abundance of pests and weeds in winter rye. Agricultural and Food Science 15: 43-60

IPCC 2007a. Summary for Policymakers. In: Climate Change 2007: The Physical Science Basis. Contribution of Working Group I to the Fourth Assessment Report of the Intergovernmental Panel on Climate Change. Solomon, S., D. Qin, M. Manning, Z. Chen, M. Marquis, K.B. Averyt, M. Tignor \& H.L. Miller (eds.). Cambridge University Press, Cambridge, United Kingdom and New York, NY, USA, $18 \mathrm{p}$.

IPCC 2007b. Summary for Policymakers. In: Climate Change 2007: Impacts, Adaptation and Vulnerability. Contribution of Working Group II to the Fourth Assessment Report of the Intergovernmental Panel on Climate Change, M.L. Parry, O.F. Canziani, J.P. Palutikof, P.J. van der Linden and C.E. Hanson, Eds., Cambridge University Press, Cambridge, UK, $16 \mathrm{p}$.

Jamalainen, E.E., 1954. Overwintering of cultivated plants under snow. FAO Plant Protection Bulletin 11: 102-105.

Johansson, A., Goud, J-K.C. \& Dixelius, C. 2006. Plant host range of Verticillium longisporium and microsclerotia density in Swedish soils. European Journal of Plant Pathology 114: 139-149.

Jylhä, K., Tuomenvirta, H. \& Ruosteenoja, K. 2004. Climate change projections for Finland during the 21st century. Boreal Environment Research 9: 127-152.

Jylhä, K., Fronzek, S., Tuomenvirta, H., Carter, T.R. \& Ruosteenoja, K. 2008. Changes in frost, snow and Baltic sea ice by the end of the twenty-first century based on climate model projections for Europe. Climatic Change 86: 441-462

Kaukoranta, T. 1996. Impact of global warming on potato late blight: risk, yield loss and control. Agricultural and Food Science in Finland 5: 311-327.

Kaukoranta, T. \& Hakala, K. 2008. Impact of spring warming on sowing times of cereal, potato and sugar beet in Finland. Agricultural and Food Science 17: 165-176.

Kevväi, R., Veromann, E., Luik, A. \& Saarniit, M. 2006. Cab- bage seed weevil (Ceutorrhynchus assimilis Payk.) and its parasitoids in oil seed rape crops in Estonia. Agronomy Research 4 (special issue): 227-230.

Kirchner, S. M., Hiltunen, L., Virtanen, E., Döring, T. F. \& Valkonen, J. P. T. 2009. Potato virus $Y$ transmitting aphids in a Finnish seed potato area. In: 8th International symposium on aphids: programme and abstracts, Catania (Italy) 8-12 June 2009. p. 167.

Kurppa, S. \& Rajala, P. 1986. Occurrence of winged aphids in potato plants and pressure for Potato virus $Y$ transmission in Finland. Annales Agriculturae Fenniae 25: 199-214

Limpert, E., Godet, F. \& Müller, K. 1999. Dispersal of cereal mildews across Europe. Agricultural and Forest Meteorology 97: 293-308.

Mäkelä, K. \& Parikka, P. 1980. Root and foot rot diseases of cereals in Southern Finland in 1975 - 1978. Annales Agriculturae Fenniae 19: 223-253.

Mela, T. 1996. Northern agriculture: constraints and responses to global climate change. Agricultural and Food Science in Finland 5: 229-234.

Menzler-Hokkanen, I., Hokkanen, H.M.T., Buchs, W., Klukowski, Z., Luik, A., Nilsson, C, Ulber, B. \& Williams, I.H. 2006. Insect problems in European oilseed rape cultivation, and how to deal with them: The OSR farmers' perspective. IOBC/wprs Bulletin 29: 91-94

Montonen, R. \& Kontturi, M. 1997. Tattarin viljelytekniikka. Maatalouden tutkimuskeskuksen julkaisuja. Sarja A 14. 51 p. (In Finnish, summary in English).

Morecroft, M.D., Bealey, C.E, Beaumont, D.A, Benham, S., Brooks, D.R., Burt, T.P, Critchley, C.N.R; Dick, J., Littlewood, N.A., Monteith, D.T., Scott, W.A., Smith, R.I., Walmsley, C. \& Watson, H. 2009. The UK Environmental Change Network: Emerging trends in the composition of plant and animal communities and the physical environment. Biological Conservation 142: 2814-2832.

Nakicenovic N., Alcamo J., Davis G., de Vries B., Fenhann J., Gaffin S., Gregory K., Grübler A., Jung T.Y., Kram T., La Rovere E.L., Michaelis L., Mori S., Morita T., Pepper W., Pitcher H., Price L., Raihi K., Roehrl A., Rogner H.-H., Sankovski A., Schlesinger M., Shukla P., Smith S., Swart R., van Rooijen S., Victor N. \& Dadi, Z. 2000. Emissions Scenarios. A Special Report of Working Group III of the Intergovernmental Panel on Climate Change, Cambridge University Press. 599 p.

Nissinen, O. 1996. Analysis of climatic factors affecting snow mold injury in first-year timothy (Phleum pratence L.) with special reference to Sclerotinia borealis. Acta Universitatis Ouluensis. Scientia Rerum Naturalium A 289. PhD Thesis of University of Oulu. $115 \mathrm{p}$.

Osborne, L.E. \& Stein, J.M. 2007. Epidemiology of Fusarium head blight on small-grain cereals. International Journal of Food Microbiology 119: 103-108.

Peltonen-Sainio, P., Hakala, K. \& Jauhiainen, L. 2011a. Climate-induced overwintering challenges for wheat and rye in northern agriculture. Acta Agriculturae Scandinavica Section B Soil and Plant Science 61: 75-83.

Peltonen-Sainio, P., Hakala, K., Jauhiainen, L. \& Ruosteenoja, K. 2009a. Comparing regional risks in producing turnip rape and oilseed rape - Impacts of climate change and breeding. Acta Agriculturae Scandinavica Section B - Soil and Plant Science 59: 129-138.

Peltonen-Sainio, P., Jauhiainen, L., Hakala, K. \& Ojanen, 


\section{AGRICULTURAL AND FOOD SCIENCE}

\section{Hakala, K. et al. Pests and diseases in a changing climate}

H. 2009b. Climate change and prolongation of growing season: changes in regional potential for field crop production in Finland. Agricultural and Food Science 18: 171-190.

Peltonen-Sainio, P., Jauhiainen, L., Hakala, K. \& Ruosteenoja, K. 2011b. Growth duration and phasing, distribution of precipitation and yielding capacity of spring cereals and rapeseed in changing climate at high latitudes. Field Crops Research, submitted.

Peltonen-Sainio, P., Rajala, A., Känkänen, H. \& Hakala, K. 2009c. Improving farming systems in northern European conditions. In: Sadras, V.O. \& Calderini, D.F. (eds), Crop Physiology. Applications for Genetic Improvement and Agronomy. Elsevier, Amsterdam. p. 71-97.

Radcliffe, E.B. \& Ragsdale, D.W. 2002. Aphid-transmitted potato viruses: The importance of understanding vector biology. American Journal of Potato Research 79: 353-386.

Ruszkowska, M. 2007. Across the transformation life cycle of Rhopalosiphum padi (L.) (Homoptera: Aphidoidea): Coevolution with temperature. Rozpravy Naukowe. Institute Ochrony Roslin Zeszyt 15. 60 p.

Serenius, M., Huusela-Veistola, E., Avikainen, H., Pahkala, K. \& Laine, A. 2005. Effects of sowing time on pink snow mould, leaf rust and winter damage in winter rye varieties in Finland. Agricultural and Food Science 14: 362-376.

Sigvald, R. 1989. Relationship between aphid occurrence and spread of potato virus $Y^{\circ}(P V Y)$ in field experiments in southern Sweden. Journal of Applied Entomology 108: 35-43.

Simon, J. C., Blackman, R. L. \& Le Gallic, J. F. 1991. Local variability in the life cycle of the bird cherry-oat aphid, Rhopalosiphum padi (Homoptera: Aphididae) in western France. Bulletin of Entomological Research 81: 315-322.

Sindberg, S., Munk, L., \& Schulz, H. 1994. Tapesia yallundae, the teleomorph of Pseudocercosporella herpotrichoides observed for the first time in Denmark. Zeitschrift für Pflanzenkrankheiten und Pflanzenschutz 101: 316-320.

Tatchell, O. M., Plumb, R. T. \& Carter, N. 1988. Migration of alate morphs of the bird cherry aphid (Rhopalosiphum padi) and implications for the epidemiology of the barley yellow dwarf virus. Annals of Applied Biology 112: 1-11.

Thomson, L.J., Macfadyen, S. \& Hoffmann, A.A. 2009. Predicting the effects of climate change on natural enemies of agricultural pests. Biological control 52: 296-306.

Tiilikainen, T.M. \& Hokkanen, H.T.M. 2008. Pyrethroid resistance of Finnish pollen beetle (Meligethes aeneus) populations - is it around the corner? EPPO Bulletin 38: 99-103.

Tiilikkala, K., Hannukkala, A., Salonen, J., Huusela-Veisto- la, E., Laitinen, P., Ojanen, H. \& Ooperi, S. 2010. Lisääntyvät kasvinsuojeluriskit ja niiden hallinta ilmaston muuttuessa. Maataloustieteen Päivät 2010. Available on the internet: http://www.smts.fi/jul2010/esite2010/002. pdf. (In Finnish.) Cited on 27 July 2010.

Tiittanen, K. 1959. Kahukärpäsen viljakasveissa aiheuttamat tuhot Suomessa vuosina 1948-1958. Schäden durch die Fritfliege (Oscinella frit L., Dipt.) bei Getreide in Finnland in den Jahren 1948-1958. Valtion maatalouskoetoiminnan julkaisuja (Die Staatliche Landwirtschaftliche Versuchstätigkeit Veröffentlichung) 178: 110125. (In Finnish, partly in German.)

Tveito, O.E., Forland, E.J., Alexandersson, H., Drebs, A., Jónsson, T., Tuomenvirta, H. \& Vaarby Laursen, E. 2001. Nordic climate maps. KLIMA report 6/2001.

Uhlig, S., Jestoi, S. \& Parikka, P. 2007. Fusarium avenaceum - The North European situation. International Journal of Food Microbiology 119:17-24.

Van Emden, H.F. \& Way, M.J. 1973. Host plants in the population dynamics of insects. In: van Emden, H.F (ed.), Insect/Plant relationships. Blackwell Scientific Publications, Oxford, UK. p. 181-199.

Van Emden, H.F. \& Harrington, R. 2007. Aphids as crop pests. CAB International, London, UK, $717 \mathrm{p}$.

Vänninen, I., Huusela-Veistola, E, Worner, S., Tuovinen, T., Nissinen, A. \& Saikkonen, K. 2010. Recorded and potential alien invertebrate pests in Finnish agriculture and horticulture. Agricultural and Food Science 20: 96-114.

Veromann, E. Luik, A. \& Kevväi, R. 2006. Oilseed rape pests and their parasitoids in Estonia. Bulletin IOBC 29: 167-174.

Willetts, H.J. \& Wong, J.A-L. 1980. The biology of Sclerotinia aclerotiorum, $\mathrm{S}$. trifoliorum and $\mathrm{S}$. minor with emphasis on specific nomenclature. The Botanical Review 46: 101-165.

$\mathrm{Xu}, \mathrm{X} .2003$. Effects of environmental conditions on the development of Fusarium ear blight. European Journal of Plant Pathology 109: 683-689.

Ylimäki, A. 1967. Root rot as a cause of red clover decline in leys in Finland. Annales Agriculturae Fenniae 6: 1-59.

Ylimäki, A. 1969. Apilamätä apilan talvehtimisen heikentäjänä Suomessa (Clover rot as a cause of poor overwintering of clover in Finland). Journal of the Scientific Agricultural Society of Finland 41: 222-242. (In Finnish, partly in English.)

Yli-Mattila, T., Kalko, G., Hannukkala, A., Paavanen-Huhtala, S. \& Hakala, K. 2010. Prevalence, species composition, genetic variation and pathogenicity of clover rot (Sclerotinia trifoliorum) and Fusarium spp. in red clover in Finland. European Journal of Plant Pathology 126: 13-27. 